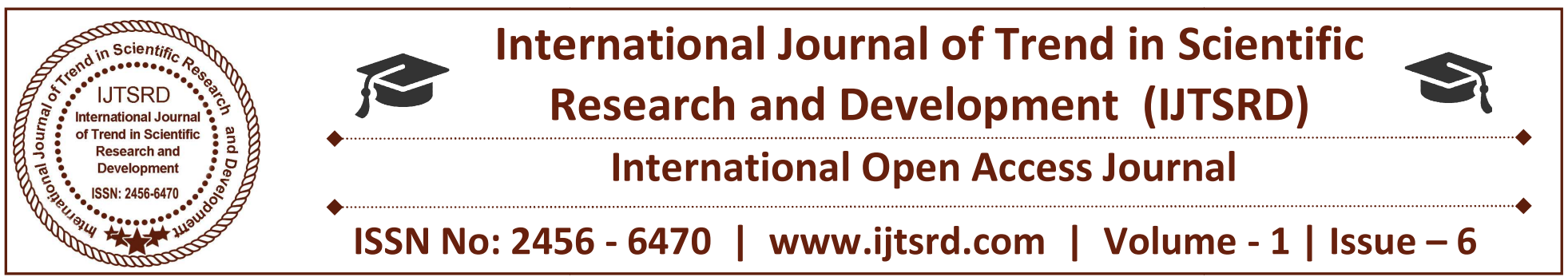

\title{
Egalitarianism in Relationship
}

\author{
Dr.V.Kiruthiga \\ Dept. of Business Administration, \\ SRM University, City Campus, Chennai, India
}

\begin{abstract}
Men and women are equal goes good in education in most part of the country, in other cases it is not at all applicable. many men doesn't know the reason for which their wives are worried or sad too. They think that they are not doing any mistakes. But a small thing may have a major impact on the relationship too. The things which men do unintentionally affect the emotional state of women. There are many issues that create problems in family. Like laziness, immaturity, Social networking and lack to express are some of the problems which men are facing and they are hindering the relationship.
\end{abstract}

\section{Keywords: hindrance, equality, immaturity}

\section{INTRODUCTION}

Over the decade many of us would have been got bored after hearing the term equality. Though men and women are equal goes good in education in most part of the country, in other cases it is not at all applicable. That to mainly when it comes to marriage it fails in many cases. There are many women who are indeed more educated than their husbands and still are treated as slaves. Equal importance is not given to them in the family. In fact though they are in greater positions than their husbands, the value is not recognized in home. Except in few houses where there is a recognition in other cases it is the opposite scenario. They may be in a top position in the organization, but in the house importance is not given. Who is to be blames for this behavior. Its literally their parents, especially their mother. In a house

where there are two children one son and one daughter. Son is given more importance. That too in some houses from the time of birth importance is given to male child. They think as though if he is pampered throughout, then he will take care of them nicely. And since girls are married off, much importance is not given to them.

In some houses the girl child is pampered so much. They in fact doesn't know to cook, wash or press clothes. They will be focusing mainly on studies. But after marriage however big post they are placed in certain activities should be mandatorily performed by women. If they do anything wrong the mother-in-law will make it a big issue. Still there are many women who look courageous and confident in the office always cry in their house.

And though both of them come from the office at the same time it is the duty of the wife to cook dinner be it any time. The the duty of the husband is to either watch TV, Playing games in mobile, watch movie or do social networking. And atlast the ultimate end will be like however good they make the food appreciation will not be given. Men think women are like a robot. Even if they are working for 24 hours a day, they won't be satisfied. They tend to identify minute mistake as possible.

Women don't expect men to do the work, the least thing which they expect is a small appreciation. This will boost them in fact to do more applauding work because she expects only small things from him. The 
husbands should try to understand the situation of the wives too. When they are tired after work they tend to while away time or remove their stress through phones or TV for what are they getting married. Is she a maid to do their day to day activity. She will also have emotions. When it is not respected the way it hurts them cannot be explained by words.

Although the paper is not dealing with serious issues, here the researcher tries to highlight that issues which men consider as minor which have a major impact on the women mind and health too. And many men doesn't know the reason for which their wives are worried or sad too. They think that they are not doing any mistakes. But a small thing may have a major impact on the relationship too. The thing which men do unintentionally affect the emotional state of women.

\section{Hindrance To Relationship}

\section{A. Lethargy}

It's a bmere laziness that create problems in most household. If a man is able to work with full interest and brisk attitude, why can't he do the same thing at home. It is the family that gives happiness to a person. Whatever they do in the work will not satisfy the management. But a small help or a kind note or gesture will have a very huge impact on the personal life. Whatever they do in the office it is not easy for them to get appreciation. But in house if they do a small thing the wife will be really happy. But men are not able to realize it. Many of them still want to lead a bachelor life. They don't want to take responsibilities. It doesn't mean that they are not interested in it, but they don't want to load themselves with household chores. It is easy for them to point out to their wives and identify the mistakes but they don't want them to be pointed out. They want to be in a safer side always. This sometimes irritates majority of women. Many women would have enjoyed their teens, they would have not at all done any work before marriage, but after marriage they are indeed forced or they rend to take the responsibility.

\section{B. Immature conduct}

Many men are immature in their behavior. Although they may be in a big post and are in a position to take many important decision in office, when it comes to home they stumble or act in an immature manner.
And indeed they doesn't want their wives to dominate too. In that sense they are clear enough. When a wife is going out with a husband, she is not expected to interfere or give any suggestions while he is talking to a third person. They tend to show their immature behavior over there. The same person who likes his wife talk, does like her to dominate him outside. And in fact they will not try to express themselves openly. Even for small issues they tend to think lots which would have been solved if they take a mere 5 minutes to discuss with their wife. But their ego or $\mathrm{n}$ immature state prohibits them to do it. Sometimes indeed they doesn't know for what they get angry itself. And they lose words for minor issues, and even though they tell sorry after that it has no value. Because the way they have hurt through word will not be replaced by sorry. They should think properly before reacting. Each time they hurt unknowingly, the gap in their relationship increases.

\section{C.Throwing stuff}

It doesn't mean that anger is the sole property for men. Even women have emotions and they also get angry. Throwing things may reduce the anger but the impact it creates on the opposite side is terrific. And it indeed creates a bad attitude among children too. They get an intention that when we are angry we can throw away things. So it means that it continues throughout the generation.

\section{$D$. Not spending time}

Now-a-days both husband and wife are working. And they don't get time to talk also throughout the day. Night is the only time when they can chat. Since the wife will also feel tired they want to complete the chores and go for sleep. But these husbands, they are not at all in a situation to understand them. They will do their so called work till late night and then ask for dinner. They don't have sympathy towards their wife. This obviously creates problems in the relationship.

\section{E. Leaving the wet towel on bed}

Though it sounds silly, it creates fights in most of the houses. Is wife a maid to do all these activities. Once or twice is okay, but if it keeps on repeating it will result in frustration. Like throwing socks and the wife has to search and wash it. They in fact don't have the tendency to wash the glass of coffee which is given to 
them. It is indeed not a big task. For a husband she can do but will he do the same thing for her. It happens only in few houses. In all the other cases the wife is responsible to take care of even the basic needs of the husband. If there is a mutual understanding it won't be felt as burden. But if it is not the case the relationship is at risk.

\section{F. Being patrons of selective hearing}

The most frustrating behavior which every wife hate. To whom will they share their feelings. But most of the husbands are selfish. They don't wish to spend time to hear to their wife. And if they hear too, they will not hear the full issue. The wives having no other option will go and talk again and again to gain their attention. But the husband's attention will be in phone or television. The don't respect the feelings of the wife. They infact don't consider it seriously. After talking if the wife questions them they will tell that their thinking was regarding certain office issue. If the situation continues mutual sharing among them will decrease.

\section{G. Mobile phones and Social networking}

The main reason for fights among the couple is due to social networking and television. Immediately after returning from office the husbands tend to while away time through social networking. The reason what they give is relaxation. So, how will wives relax. When they see the husbands relaxing they tend to get angry. They feel like is it the duty of the wives only to do the chores and they feel bad. The husband should think of the wives too. Little help which they do have a major impact on their relationship in the positive side. This they should realize to safeguard their relationship.

\section{H. Always asking for their things}

The husbands expect their wives to keep everything in an organized manner. But they will not manage themselves. Even though they know to do, their thinking is like since wife is there why they should do. If a wife goes somewhere and returns after few days the house will be like a mess. Some men don't have the tendency to throw the garbage too. But the same person expects his oife to maintain a clean home. If it is not clean they tend to get angry and throw away things. If they are not able to find a single item unless the wife finds it the husband will always stay irrited. But if the wife is searching for something the immediate reply will be like they don't know to keep their things properly. They will indeed not strain them to search for things, instead they will shout at their wives.

\section{Never strain themselves in planning and showering love}

Men are the ones who flop the plan frequently. In fact they do not want to take any responsibility. Because if the plan foes wrong they don't want to be blamed. So for planning also they give the responsibility to their wives. They doesn't like to give surprises to the wives. They don't care about the expectation of the wife. They doesn't like to plan and make wife happy. Love without expressing is a mere waste. By keeping within oneself the love will not have any value. They doesn't know to express, and even after seeing the wife expressing they will not repeat also. Small surprises, little gifts and cute gestures will impress their wives. But many men don't care about all these, they will always be in their own way. They should change themselves. They need not shower love always but atleast occasionally they can do it. Occasional changes can boost the love life.

\section{Conclusion}

We can conclude by saying that on order to lead a happy married life, the co-operation of the husband is very essential. He can make a lively life, through the small gestures. Equality doesn't mean in going to jobs and studying. Or earniong equally or sometimes greater than men. That is not at all equality, the wives should be respected in terms of feelings and emotions. They should be treated with dignity and respect. We are not concluding that all men are bad. Everyone is good, but each one of them have some negative aspects and even women have that. But if men are able to make certain small changes in the life style then most of the problems in life can be eliminated and the life will bloom. 